\title{
Primary Hypertrophic Osteoarthropathy with Gastric Hypertrophy
}

XUE-FENG SUN, MD, Department of Internal Medicine; QING-JUN WU, MD, Department of Rheumatology; YA-LAN BI, Department of Pathology; YONG HOU, MD; MENG-TAO LI, MD; WEN ZHANG, MD; XUAN ZHANG, MD; YAN ZHAO, MD; XIAO-FENG ZENG, MD;

FENG-CHUN ZHANG, MD; FU-LIN TANG, MD, Department of Rheumatology, Peking Union Medical College Hospital, Chinese Academy of Medical Science, and Peking Union Medical College, Beijing, China. Address correspondence to Dr. Q-J. Wu; E-mail: wqjzyl@gmail.com.

J Rheumatol 2011;38:959-60; doi:10.3899/jrheum101077

Primary hypertrophic osteoarthropathy (HOA) is a rare congenital disease that is not well recognized. Gastric hypertrophy will be infrequently involved; only 3 case reports describe this scarce manifestation in the English-language literature ${ }^{1,2,3}$.

A 19-year-old Chinese male presented with a 4-year history of thickened skin and joint pain and swelling. Marked sweating and intermittent low fever were also noted. He had been treated with methotrexate for 8 months and Chinese traditional medicine for 9 months, with no improvement. Examination revealed distinct grooves on his forehead and thickened scalp (Figure 1A). His wrists and hand joints were slightly swollen, and skin distal to wrists was darkened (Figure 1B). Symmetrical nonpitting edema of knees, ankles, and feet was observed (Figure 1C). Laboratory tests revealed elevated inflammatory markers, normal growth factor level, and normal immunological markers. Malignancy was excluded after examinations. Bone radiographs revealed thickened cortical plate and periosteal new bone formation in bilateral tibio-fibula, femur, radio-ulna and long bones of hands and feet (Figure 1D). Barium radiography showed hypertrophic mucosa of gastric body and fundus, with normal esophagus, small intestine, and ileocecal junction (Figure 2A). Gastroscopy also revealed gyruslike hypertrophic and rough mucosa at gastric body and fundus (Figure 2B). Biopsy results showed mildly enlarged mucosa cells, with interstitial edema and inflammatory cell infiltration (Figure 2C). He was diagnosed as having primary HOA with gastric involvement, and treated with nonsteroidal antiinflammatory drugs and $\mathrm{H}_{2}$-receptor antagonist.

\section{REFERENCES}

1. Lam SK, Hui WK, Ho J, Wong KP, Rotter JI, Samloff IM. Pachydermoperiostosis, hypertrophic gastropathy, and peptic ulcer. Gastroenterology 1983;84:834-9.

2. Venencie PY, Boffa GA, Delmas PD, Verola O, Benkaidali I, Frija $\mathrm{J}$, et al. Pachydermoperiostosis with gastric hypertrophy, anemia, and increased serum bone Gla-protein levels. Arch Dermatol 1988;124:1831-4.

3. Narayanan S, Mohamed Gani VM, Sundararaju V. Primary hypertrophic osteoarthropathy with hypertrophic gastropathy. J Clin Rheumatol 2010;16:190-2. 


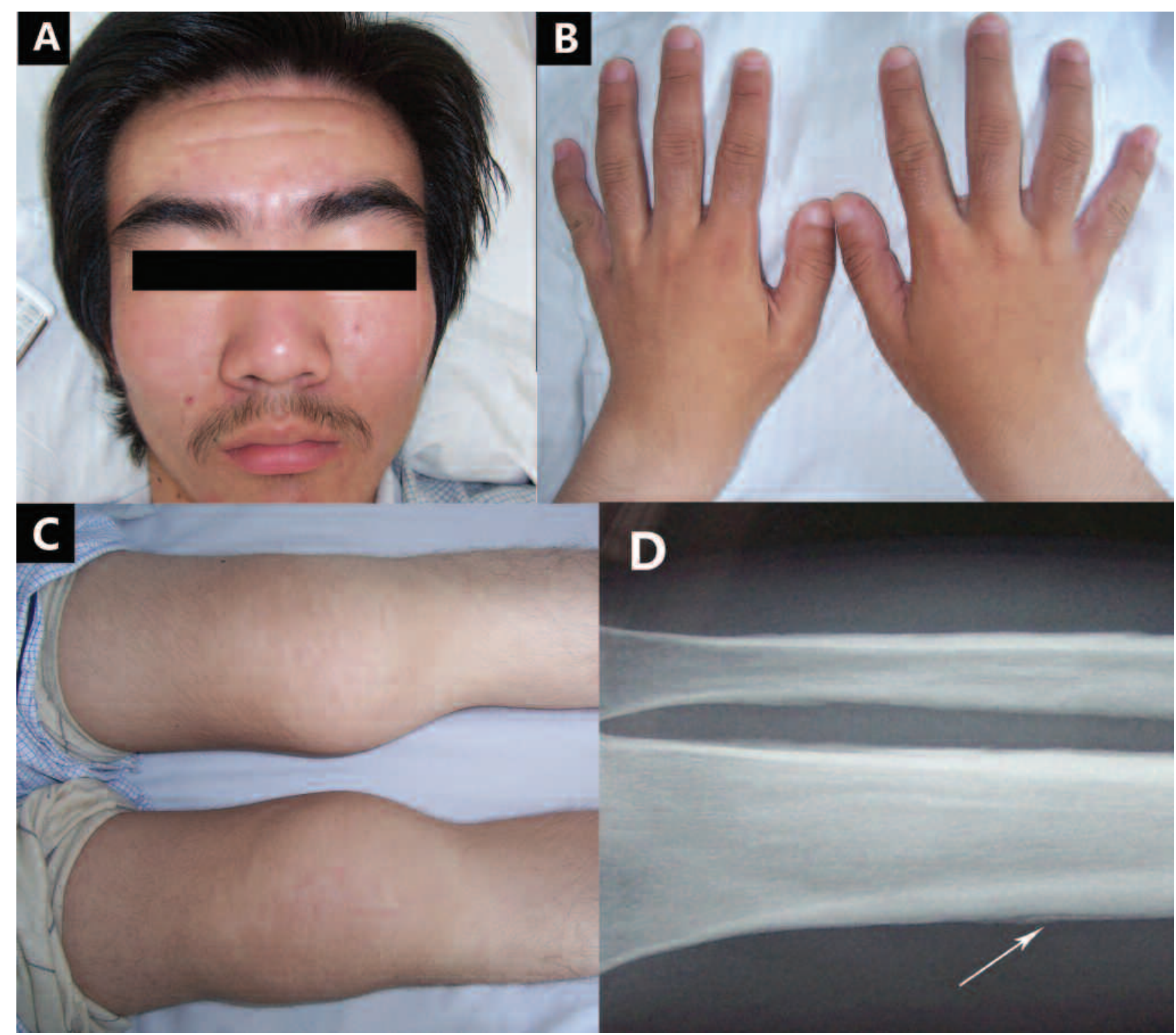

Figure 1. A-C. Dermal and bone manifestations of primary hypertrophic osteoarthropathy. D. Radiograph reveals thickened cortical plate and periosteal new bone formation in bilateral tibio-fibula (arrow).

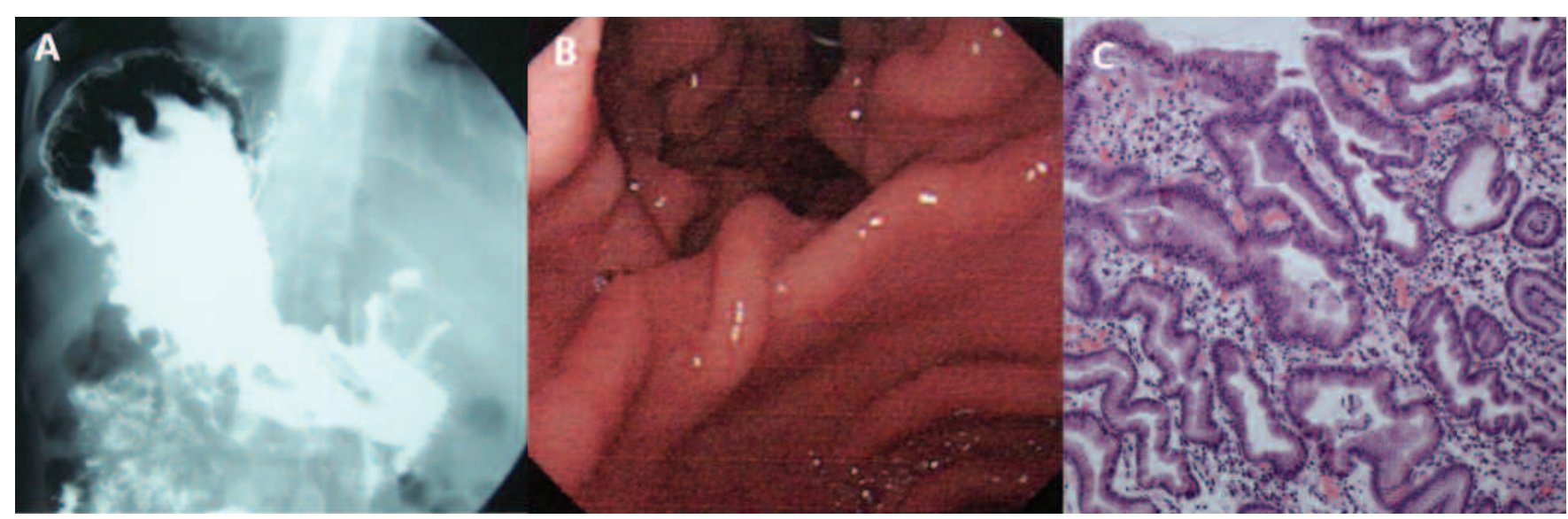

Figure 2. A. Barium radiography; and B. gastroscopy show gyrus-like mucus folds at gastric body and fundus. C. Gastric mucosa biopsy showed mildly enlarged mucosa, with interstitial edema and inflammatory cell infiltration.

\section{Personal non-commercial use only. The Journal of Rheumatology Copyright @ 2011 . All rights reserved.}

